\title{
Figuras de retórica nos Responsórios para Quarta Feira Santa de Antônio dos Santos Cunha
}

\author{
Edilson Rocha (UFSJ, São João del-Rei, MG) \\ ediassuncao@hotmail.com
}

Resumo: Este artigo busca identificar figuras de retórica musical na obra Responsórios para Quarta Feira Santa de Antônio dos Santos Cunha (1775?-1822?). Apresenta um breve estudo sobre o compositor e sobre a aplicação litúrgica da composição e conclui sobre a importância deste tipo de análise para a interpretação.

Palavras-chave: Retórica musical; Antônio dos Santos Cunha.

\section{Musical Rethoric in the Responsórios para Quarta Feira Santa by Antônio dos Santos Cunha}

Abstract: This paper tries to identify structures of musical rhetoric in the masterpiece Responsórios para Quarta Feira Santa by Antônio dos Santos Cunha (1775?-1822?), it also presents a brief study about the composer and the liturgical use of his composition, and shows how this analysis can help to create conceptions of performance.

Key-words: Rhetoric; Antônio dos Santos Cunha.

\section{Introdução}

Antônio dos Santos Cunha foi um compositor pouco prolífico, entretanto, suas obras apresentam muito fôlego e 0 vasto emprego de recursos composicionais. Habitualmente a serviço do texto, estes buscam reforçar o aspecto dramático de um repertório voltado para o cerimonial da liturgia católica. É o caso dos Responsórios para Quarta Feira Santa, obra composta para a celebração do Ofício de Trevas da Semana Santa, liturgia em desuso praticamente em todo o mundo, mas celebrada com adaptações na centenária São João del-Rei, MG, até os dias de hoje. É nesta cidade que se encontram os originais desta obra. Trata-se de manuscritos autógrafos, que se apresentam encadernados e possuem uma característica singular: estão escritos em formato de "grade", como se apresentam as atuais edições para leitura pelo regente. Tal disposição é muitíssimo rara dentre a documentação remanescente relativa à música mineira daquela época e infelizmente, sua data de criação não pode ser determinada com exatidão.

Os Responsórios para Quarta Feira Santa, também e talvez mais propriamente chamados de Matinas para a Quinta Feira Santa, foram compostos originalmente para cordas, trompas diatônicas, clarinete em Dó, flauta, coro a quatro vozes e solistas. É dividido em três noturnos, e cada um por sua vez é dividido em outras três seções de unidade cerimonial, sendo cada uma destas chamadas genericamente responsório, perfazendo um total de nove. Cada um destes responsórios é também dividido em outras três partes, chamadas responso, prece e verso. Estas divisões musicais e textuais estão subordinadas à prática litúrgica, na qual consta também o repetendum, que é a repetição da prece após o verso nos responsórios $1{ }^{\circ}, 2^{\circ}$, $4^{\circ}, 5^{\circ}, 7^{\circ}$ e $8^{\circ}$ e repetição do responso e da prece no $3^{\circ}, 6^{\circ}$ e $9^{\circ}$. Esta estrutura, empregada desde a idade média, é a mesma encontrada nos Responsórios para Quinta e Sexta Feiras Santas, e todas estas obras representam os sentimentos e passagens que animaram Cristo às vésperas de sua crucifixão.

Muito pouco se sabe sobre Antônio dos Santos Cunha, pois praticamente não existe documentação conhecida que ofereça informações a seu respeito. Possivelmente era branco, diferentemente da maioria dos músicos radicados nas Minas Gerais do século XIX e muito prova- 
velmente permaneceu em São João del-Rei entre 1800 e 1815. (VIEGAS, 2004). A análise de suas obras em conjunto com a pouca documentação existente permite supor, ainda que de maneira muito frágil, que teria nascido por volta de 1775 e seguramente estaria vivo ainda pelos idos de 1822. A partir desta data não há informação alguma a seu respeito e tudo que resta são meras conjecturas. Existe a grande possibilidade de que fosse português, hipótese reforçada pela constatação do seu grande conhecimento musical sobre instrumentação, orquestração, harmonia, pelo domínio de estruturas composicionais como a fuga, uso de progressões simétricas, notas pedais e pelo emprego de figuras de retórica musical e de passagens virtuosísticas. Tais conhecimentos podem não ter sido adquiridos em terras brasileiras.

\section{Retórica musical}

A retórica é um recurso de comunicação já conhecido pelos gregos clássicos, empregado pelos oradores e objetivava basicamente a condução dos sentimentos da assistência na direção pretendida pelo interlocutor. A partir do final do século XVI, os teóricos começaram a estudar a questão da retórica voltada para a prática musical, provavelmente movidos pela estreita relação entre a palavra e a música vocal típica da época. Nos séculos XVII e XVIII, entretanto, foram sendo ainda mais estreitados os laços entre retórica e música (WILSON, 2001). 0 crescimento da música instrumental sob tal influência, ensejou a continuidade do emprego de recursos retóricos mesmo quando esta se tornou completamente independente da palavra. Neste contexto, a música de Antônio dos Santos Cunha, teve como elemento importante o emprego de figuras de retórica musical no reforço de passagens dramáticas, colocando coro e orquestra a serviço da religiosidade e do sentimento pio a ser celebrado.

Uma característica interessante na obra deste compositor é a aparente falta de preocupação com a clareza das palavras, mas pode-se perceber o cuidado com o sentimento que elas expressam. Tal pode ser observado em passagens onde ocorrem textos distintos sendo executados simultaneamente ou em textos iguais cantados defasados, ao mesmo tempo em que ocorrem sobre estruturas e figuras de retórica que reforçam o momento litúrgico. Estes recursos composicionais aparentemente pretendem causar nos expectantes certo grau de êxtase, proporcionado por um nível de dramaticidade levado ao extremo. 0 reforço da retórica textual pela retórica musical amplia a efetividade do conteúdo expressivo a ser comunicado.

Muitas passagens apresentam recursos típicos da ópera, sendo esta uma importante referência na obra do compositor. A execução de melismas vocais que exigem amadurecimento dos solistas, bem como a utilização de notas extremas e saltos melódicos difíceis, concorrem para trazer para a liturgia, esta normalmente mais contida, uma concepção musical que se aproxima mais do espetáculo, não obstante a necessidade de ser muitíssimo bem dosada esta aproximação no momento da execução.

\section{Retórica musical nos Responsórios para Quarta Feira Santa}

Antônio dos Santos Cunha utiliza figuras de retórica musical para dar ênfase ou relevo a passagens dramáticas buscando ressaltar determinadas emoções. Emprega artifícios de retórica livre, construções musicais que simulam de maneira alegórica determinadas características expressas pelo texto, estados de espírito ou ações. É o caso das figuras pontuadas empregadas sobre a frase litúrgica, "vieram com paus e pedras1", provavelmente para representar Cristo sendo fustigado com lanças pelos seus captores, na prece do responsório $9^{\circ}$. Tais procedimentos de reforço retórico podem justificar a utilização de um fugato da prece $2^{2}$, sobre o texto "fugireis e serei imolado por voz2", ou mesmo o uníssono geral ascendente sobre o texto "enforcou-se3" no final da prece $4^{a}$.

Pode ser também uma figura retórica empregada com sutileza a estrutura no começo do responso $6^{\circ}$, onde há um compasso de orquestra em uníssono, para em seguida atacarem todas as vozes, menos uma, sobre o texto "um dos meus discípulos me trairá hoje4". A ausência do tenor, cuja entrada acontece três compassos depois pode significar a ausência de Judas, que irá se retirar para realizar a traição. Tal emprego de figuras de retórica pode ser identificado no restante das obras do autor.

Se o emprego de retórica livre demonstra a sensibilidade do compositor em relação aos elementos da liturgia e com sua obra, o emprego de figuras retóricas sistematizadas demonstra a profundidade do seu conhecimento teórico. Devido ao grande número delas e ao fato de algumas classificações poderem se tornar imprecisas e conflitantes, foram analisadas somente as figuras que forneceram maior identidade aos Responsórios para Quarta Feira Santa. Foi usado como referência principal o verbete Rethoric do New Grove Dictionary (WILSON, 2001).

\section{Passus duriusculus}

Devido às características próprias dos Responsórios para Quarta Feira Santa, que retrata momentos dramáticos da paixão de Cristo, a figura passus duriusculus tem destaque. Trata-se do emprego de segundas menores descendentes, figura habitualmente utilizada para expressar pesar e tristeza. Aparece no $2^{\circ}$ verso e apresenta características interessantes no seu emprego. Uma delas é a de ser apresentada pela primeira vez no solo da introdução instrumental, c. 72, por violino I, viola e clarinete. Quando o solo é novamente apresentado pelo contralto solista, ressurge dobrado somente pelo violino I, mas na repetição, a figura não é apresentada pela voz, mas somente pelo violino. 0 texto diz "Eis que se aproxima a hora e 0 Filho do homem será entregue às mãos dos pecadores" ${ }^{5 "}$. 0 autor emprega a mesma figura retórica com as mesmas notas, mas com valores expandidos, configurando-se uma repetição do motivo nos c. 93 e 95.

No $3^{\circ}$ verso, o passus duriusculus é ainda mais importante para a criação de uma característica marcante no 

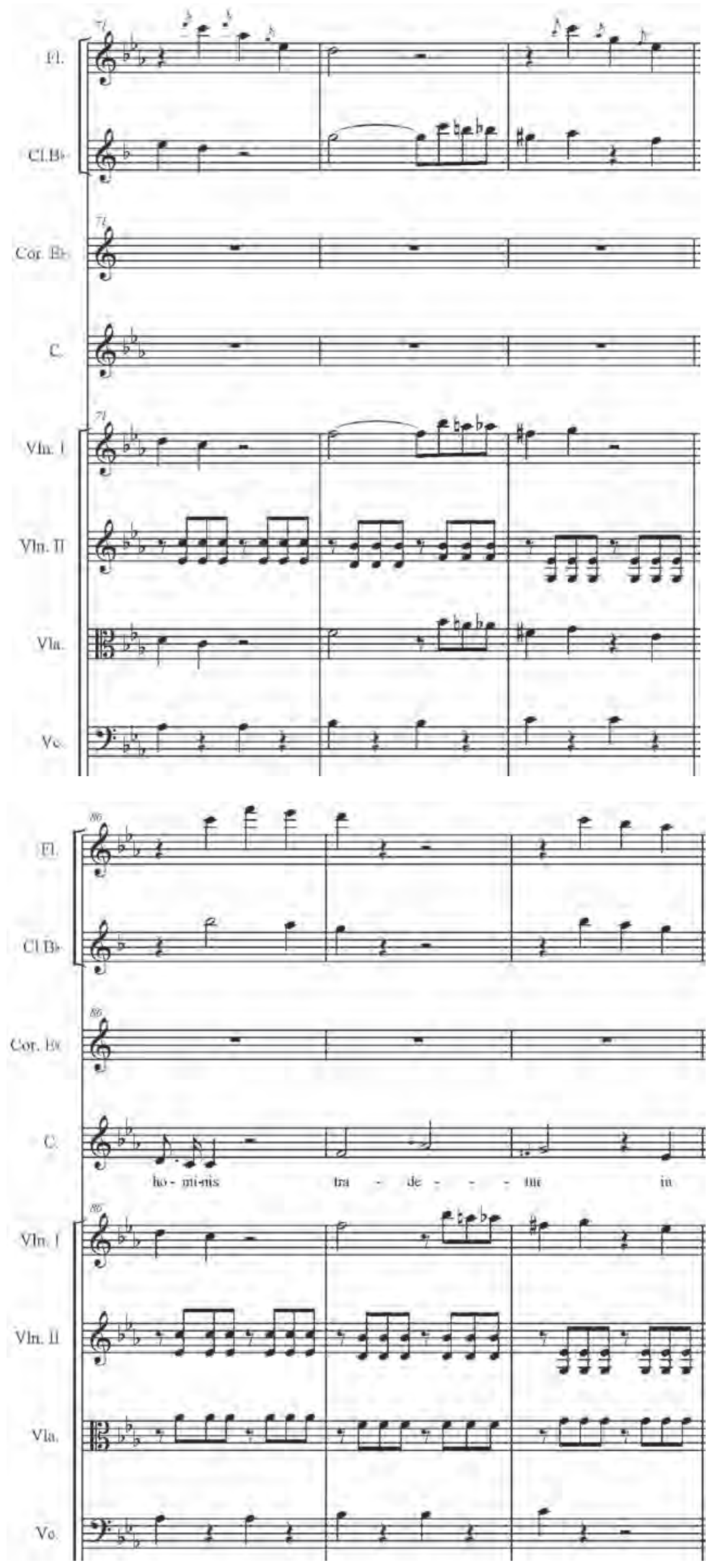

Ex.1: passus duriusculus no verso $2^{\circ}$. 
discurso musical. Por se tratar de um dueto, onde a figura retórica é tratada imitativamente, suas repetições são especialmente expressivas, ressaltando o caráter pesaroso do texto "Tomou sobre si nossas fraquezas e carregou nossas dores". ${ }^{6}$

No exemplo 03 podem-se ver os compassos iniciais em que é apresentada pela primeira vez a figura retórica entre violino I e II. A entrada dos solos de soprano e contralto, nos c. 96 e 98 respectivamente, é realizada em dobramento reproduzindo a introdução instrumental e obedecendo ao mesmo esquema; voz aguda apresentando o primeiro motivo e depois a voz grave. Nos c. 132 e 133 ocorre uma inversão da figura retórica, sendo apresentada primeiro pelo tenor, dobrado pelo violino I e flauta e depois por soprano dobrado pelo violino I e clarinete (ex.04). Neste caso pode-se observar que o violino apresenta os dois motivos desta figura retórica em sequência.

No verso $6^{\circ}$, a figura retórica foi escrita para o soprano solista, aparecendo pela primeira vez no c.117 e 118, dobrado em oitavas pelas violas. Nesta passagem o texto diz: "...há de me entregar às mãos dos pecadores". É reapresentado no c.126 com variação rítmica e também nos c.164 e 172, neste último na tonalidade da dominante.

\section{Patopeia}

É figura retórica recorrente na obra de Antônio dos Santos Cunha. 0 autor, na maioria das vezes, não chega a criar longos trechos onde a patopeia imprima uma característica motívica central, mas seu emprego indica o nível de detalhe com qual tratou sua obra. Aparece sempre associada a passagens litúrgicas onde a dramaticidade e sentimentos de terror, medo ou tristeza são sugeridos pelo texto litúrgico, preferindo sua construção com os instrumentos, não obstante também emprega-la eventualmente com as vozes. É constituida basicamente por notas estranhas ao acorde, ou dissonâncias passageiras que podem surgir como bordaduras.

No verso $1^{\circ}$, a patopeia aparece como preparação para a entrada do texto "vigiai e orai", no c.97, em sequência pelos violino I, violino II e viola, dobrados respectivamente por flauta, clarinete e trompa.

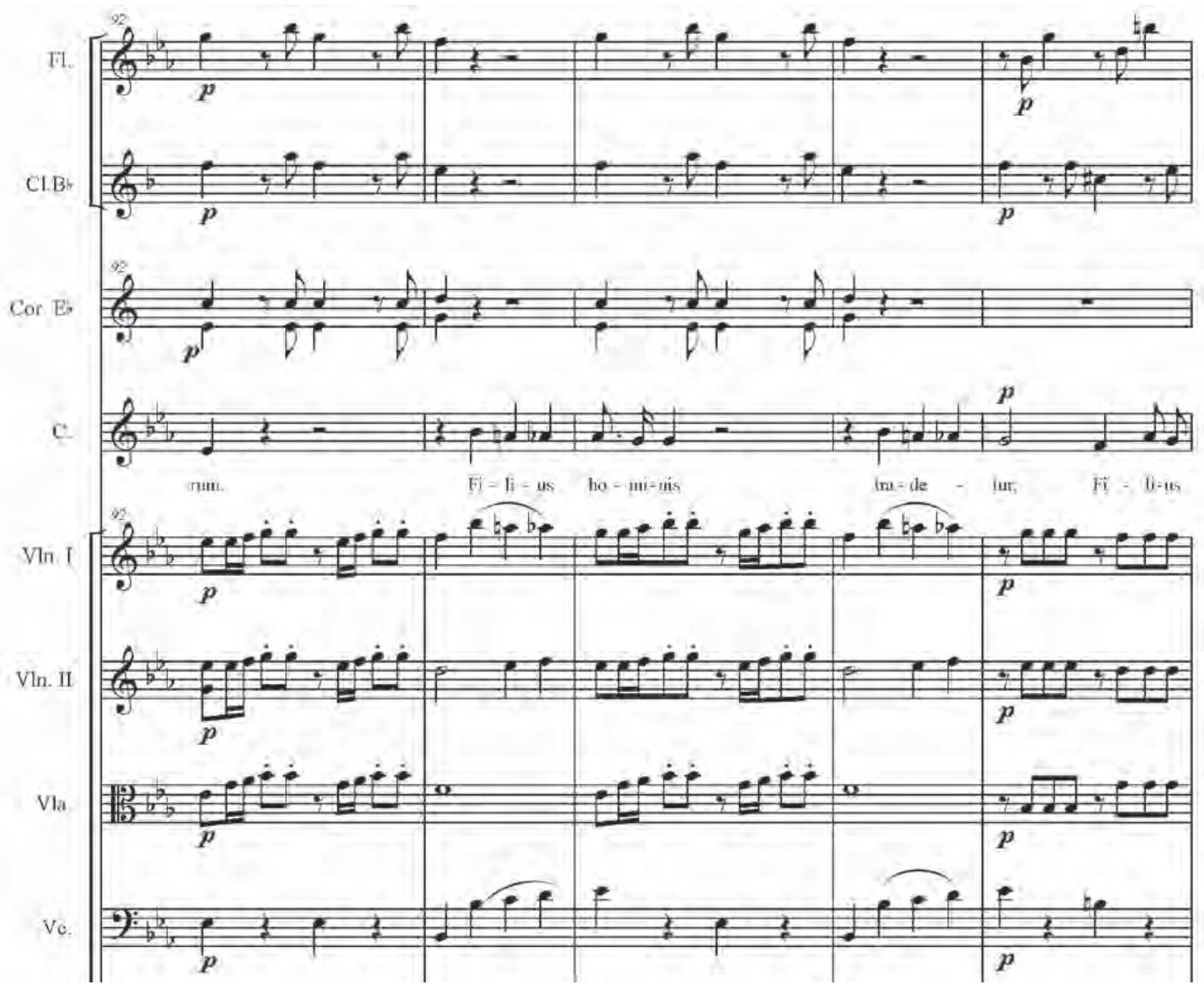

Ex.2: repetição do motivo, desta vez expandido. 


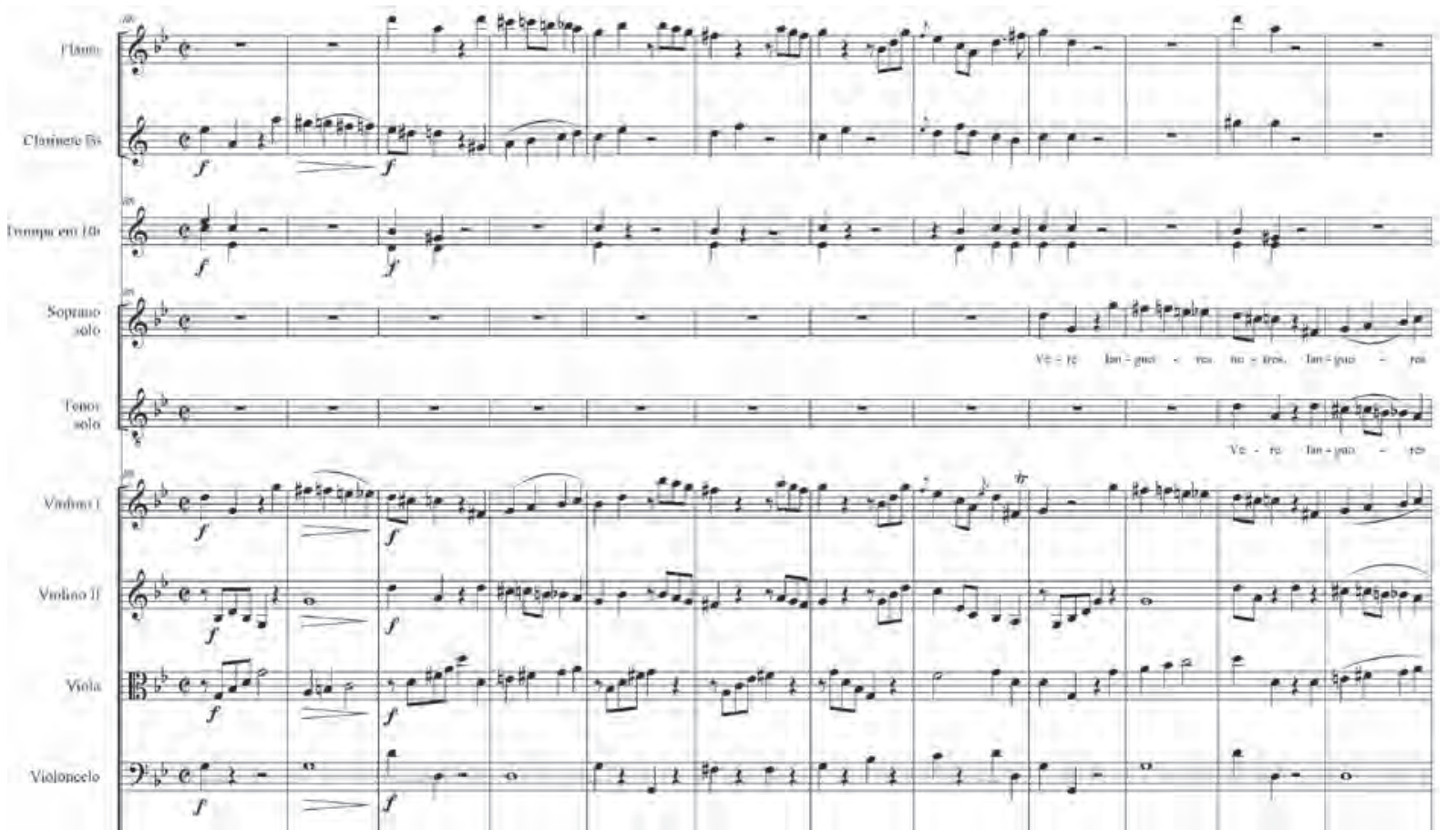

Ex.3: passus duriusculus, introdução do verso $3^{\circ}$.

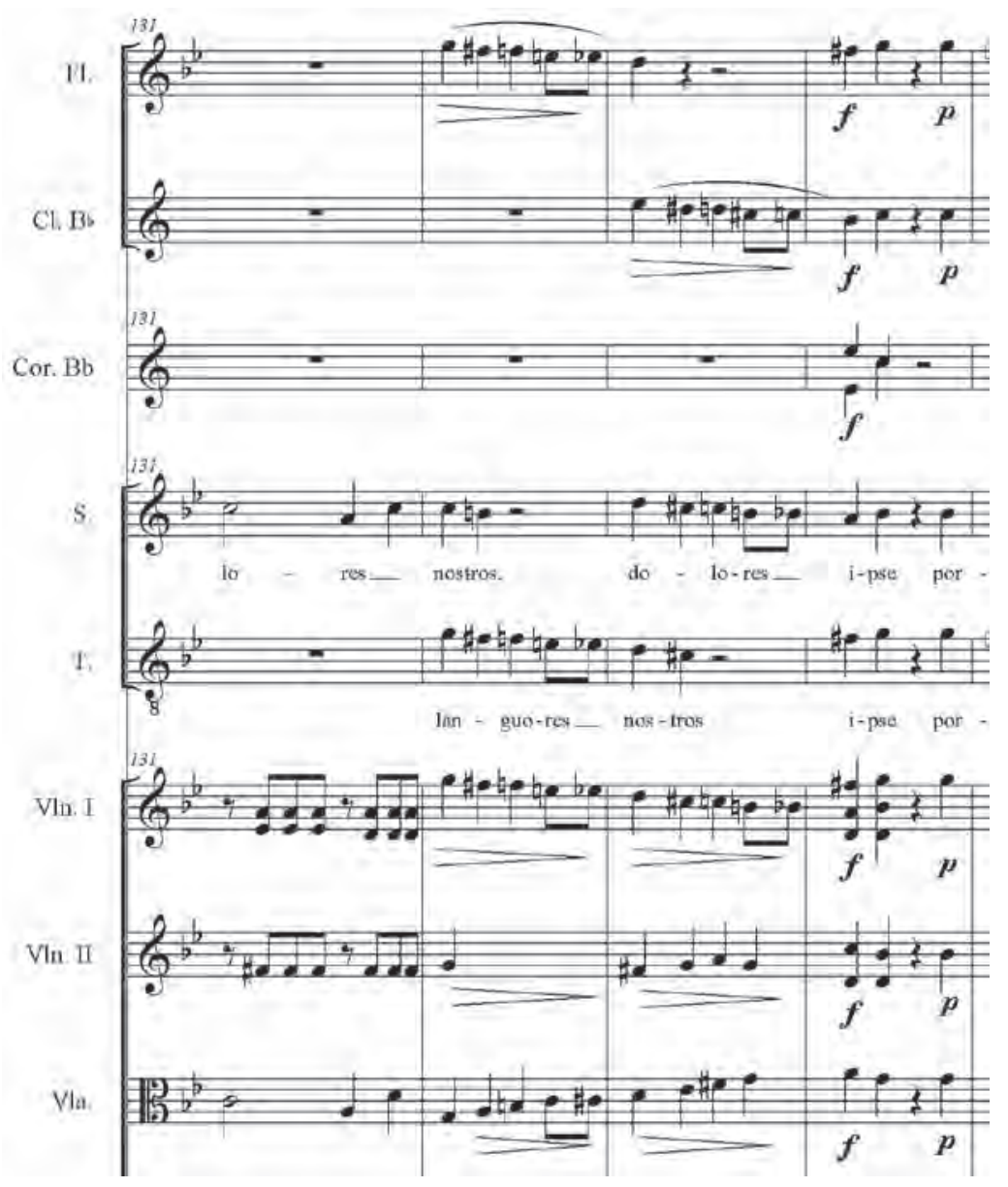

Ex.4: passus duriusculus, apresentados em outra sequência. 


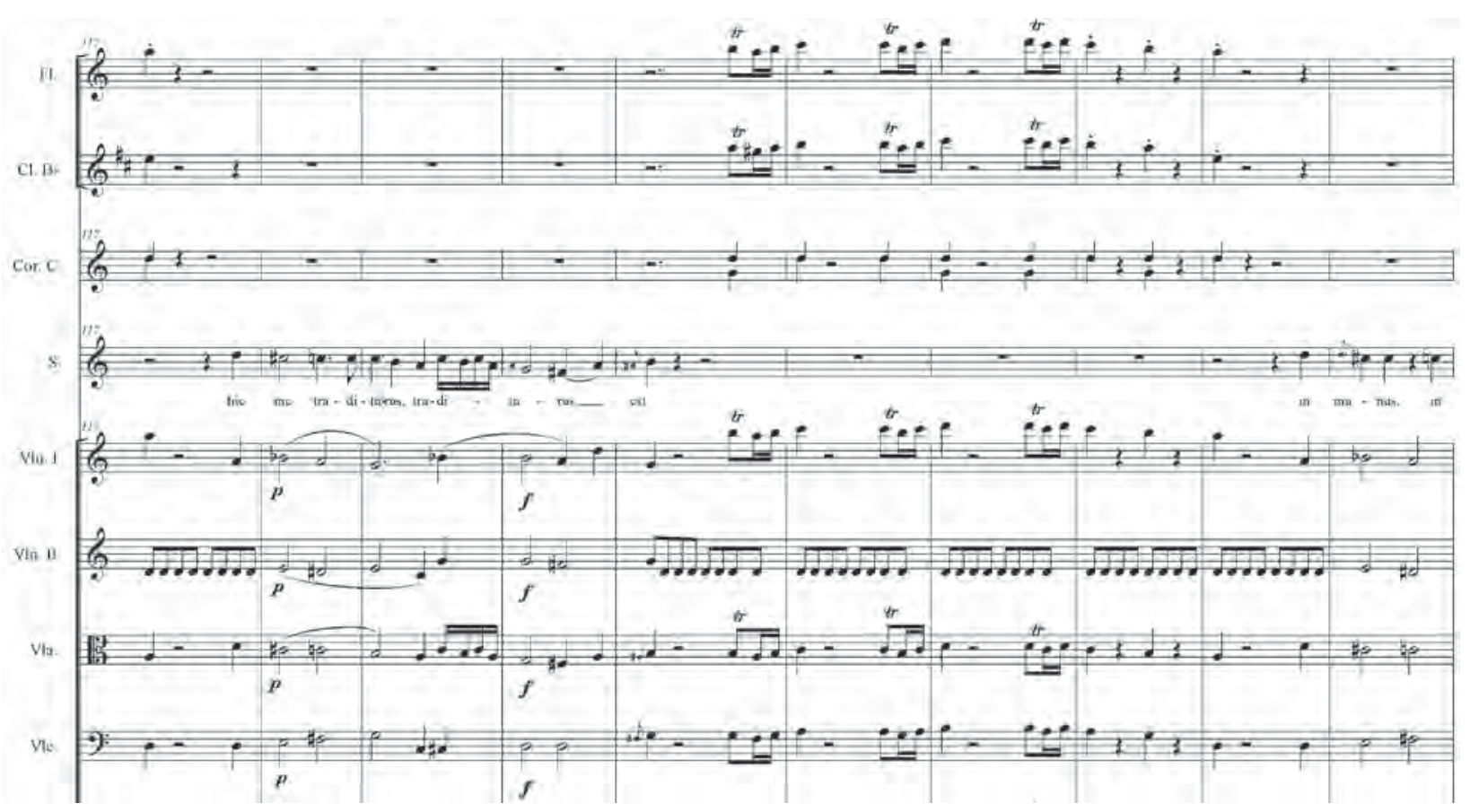

Ex.5: figura retórica repetida.

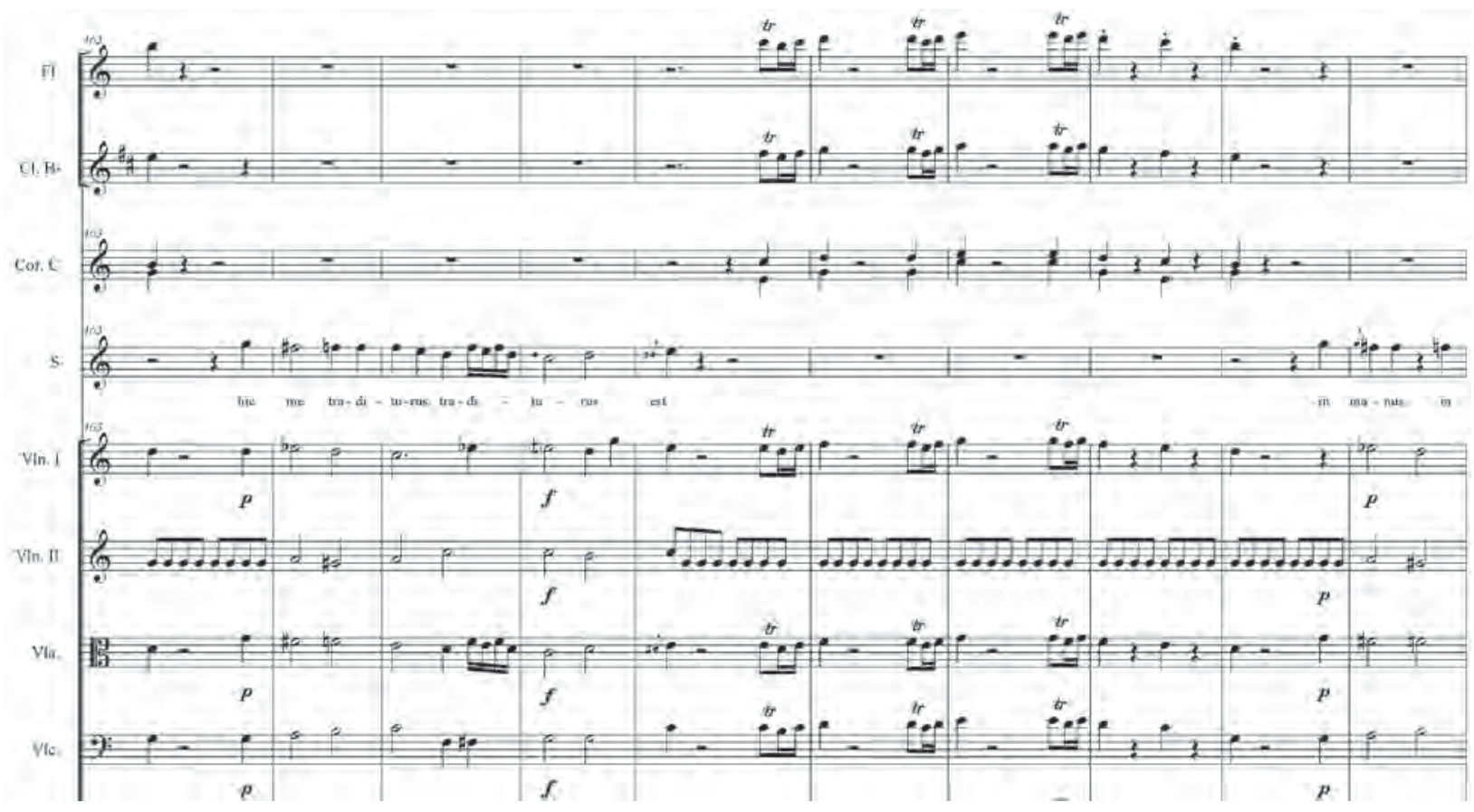

Ex.6: repetição do passus duriusculus em nova tonalidade.

É empregada também como um rápido comentário instrumental do violino I entre passagens vocais, no c.108, quando ocorre uma brusca rarefação do instrumental. Tal construção contribui para destacar a figura retórica que reforça o texto "para não cairdes em tentação".

Na prece $2^{\text {a }}$ ocorre nos c. 47 a 50 , e configuram uma subseção na qual a patopeia é bem característica da sonori- dade deste trecho. Interessante notar que acontece em dobramentos entre vozes e instrumentos, e algumas notas desta configuração não chegam a ser dissonantes. Ocorre sobre o texto "fugireis e serei imolado por vós". No verso $2^{\circ}$ a patopeia foi escrita a partir do c. 115 até o 118, nas madeiras ora na flauta, ora no clarinete. A indicação do autor para o trecho é dolce, o que sugere sua realização de maneira discreta, no espírito do tre- 


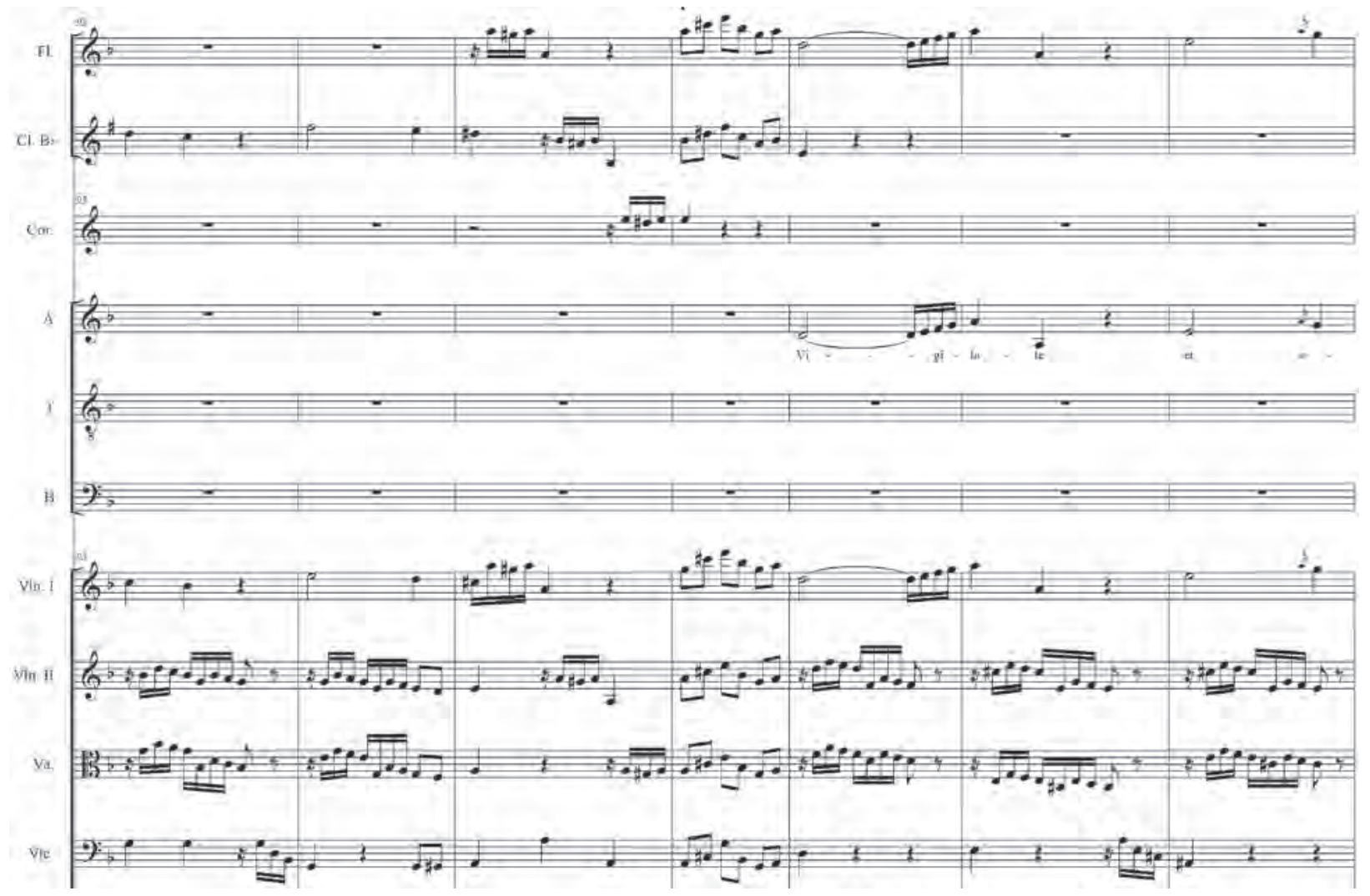

Ex.7: patopeia preparando a entrada do solo.

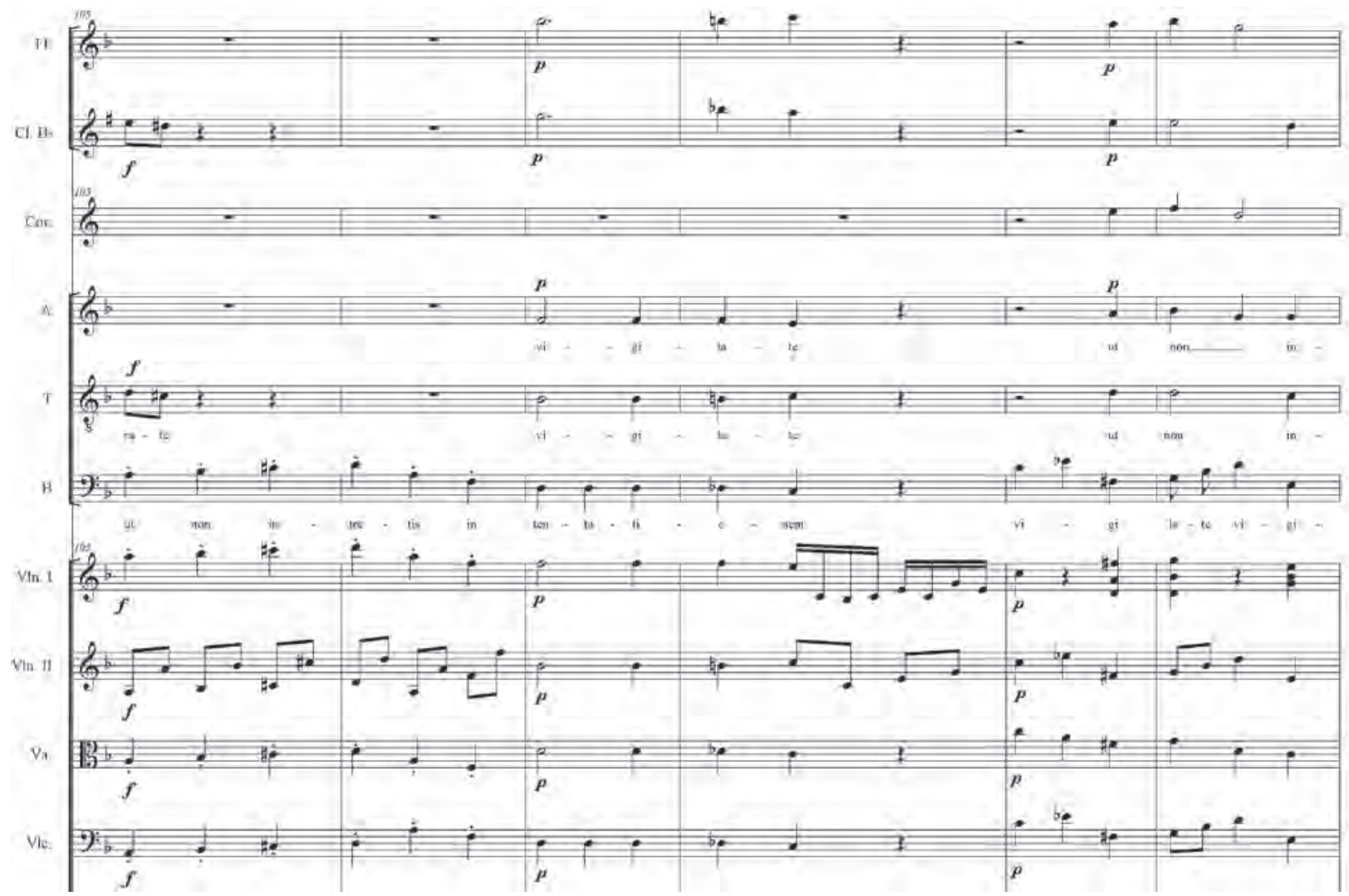

Ex.8: patopeia no c. 108 do verso $1^{\circ}$. 
cho, que comenta: "eis que se aproxima a hora e o Filho do homem será entregue".

No verso $3^{\circ}$, a patopeia é empregada principalmente nos finais de seção, funcionando proximamente como arremate, como se pode ver no c.104 a 106. Santos Cunha toma cuidado para que as mesmas não concorram com as melodias dos solistas, funcionando quase como contracantos com a duração de um ou dois tempos sobre pausas do solo, que canta " tomou sobre Si nossas fraquezas".

$\mathrm{Na} 4^{\text {a }}$ prece apresenta a mesma característica de comentário instrumental após a intervenção do coro e aparenta reforçar o aspecto dramático do texto " jogou fora o preço do sangue e por fim se enforcou", c.44 a 48.

Na prece $5^{\text {a }}$ a patopeia é empregada simultaneamente ao coro, do c.44 ao 50, nos violinos I. Apresenta o texto "por alguns dinheiros entregou Cristo".

No verso $6^{\circ}$, a figura retórica acontece em quatro passagens, que podem ser agrupadas duas a duas, nos c. 119, 127 e c. 165 e 173 . São executadas pelo contralto solista, dobrado em oitavas pelas violas. Trata-se de pas- sagens muito dissonantes, com segundas harmônicas seguidas que emprestam uma sonoridade "dura", muito empregada por Antônio dos Santos Cunha. É o que se pode ver nos exemplos 06 e 07, logo na sequência dos passus duriusculus.

Na prece 8a, a figura retórica tem suma importância, sendo elemento central e estruturador desta seção de unidade funcional. É executado pelas cordas do início, c.55 até o final da prece. Apresenta o texto "Não vedes que Judas não dorme e se apressa a me entregar aos inimigos ${ }^{7}$ ?".

\section{Catábase}

0 movimento melódico catabático, composto por escalas descendentes normalmente construidas com figuras curtas, é dos mais comuns nos Responsórios, entretanto só foram consideradas como catábase as escalas que imprimiram característica determinante na construção do discurso musical, ou que se estenderam por maior número de compassos, criando assim um fenômeno musical menos passageiro. Desta forma, passagens melismáticas, arremates simples e transições não foram consideradas. Habitualmente expressam sentimentos ou imagens negativas.

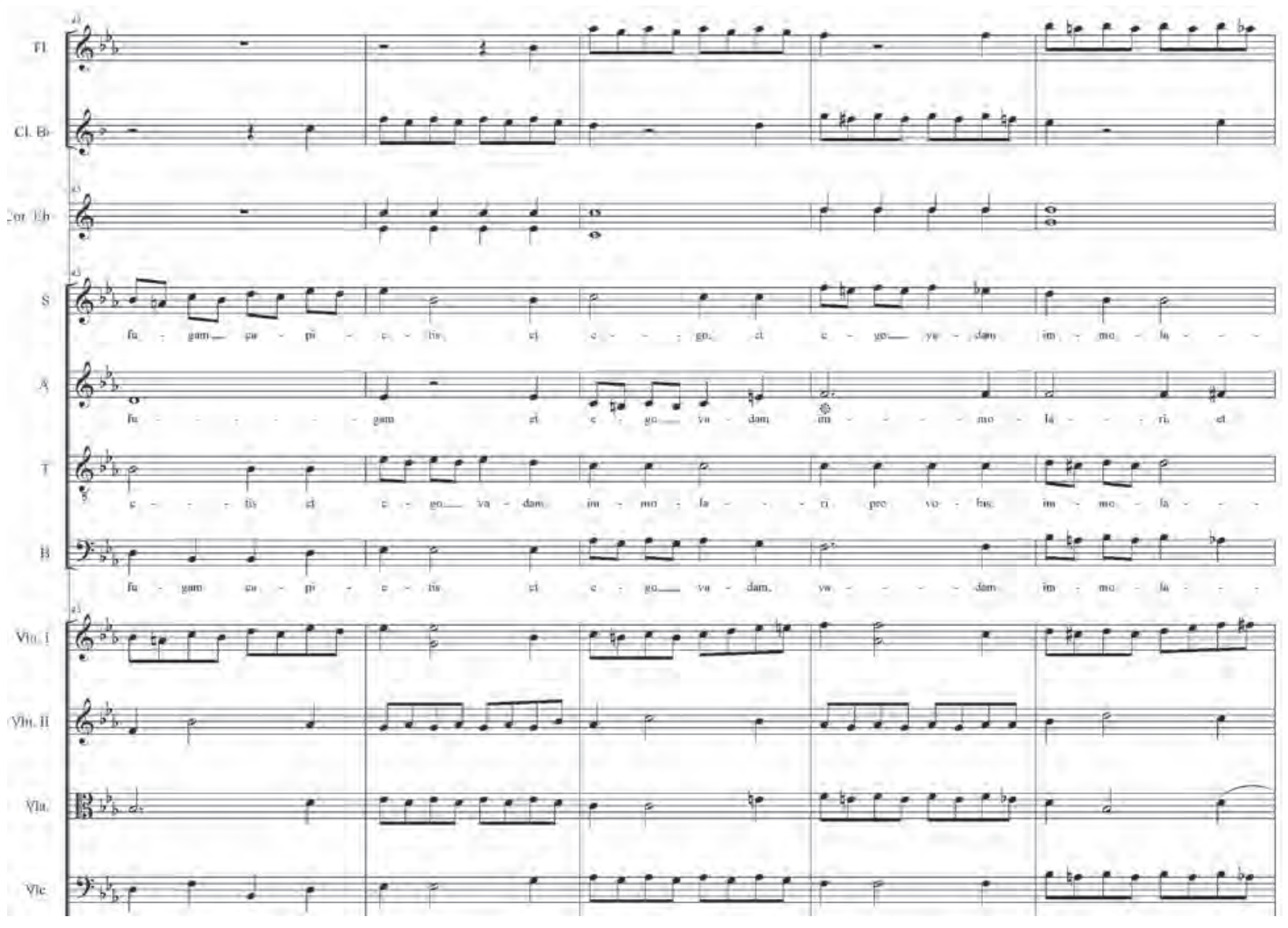

Ex.9: patopeia com coro e cordas, prece $2^{\text {a }}$. 


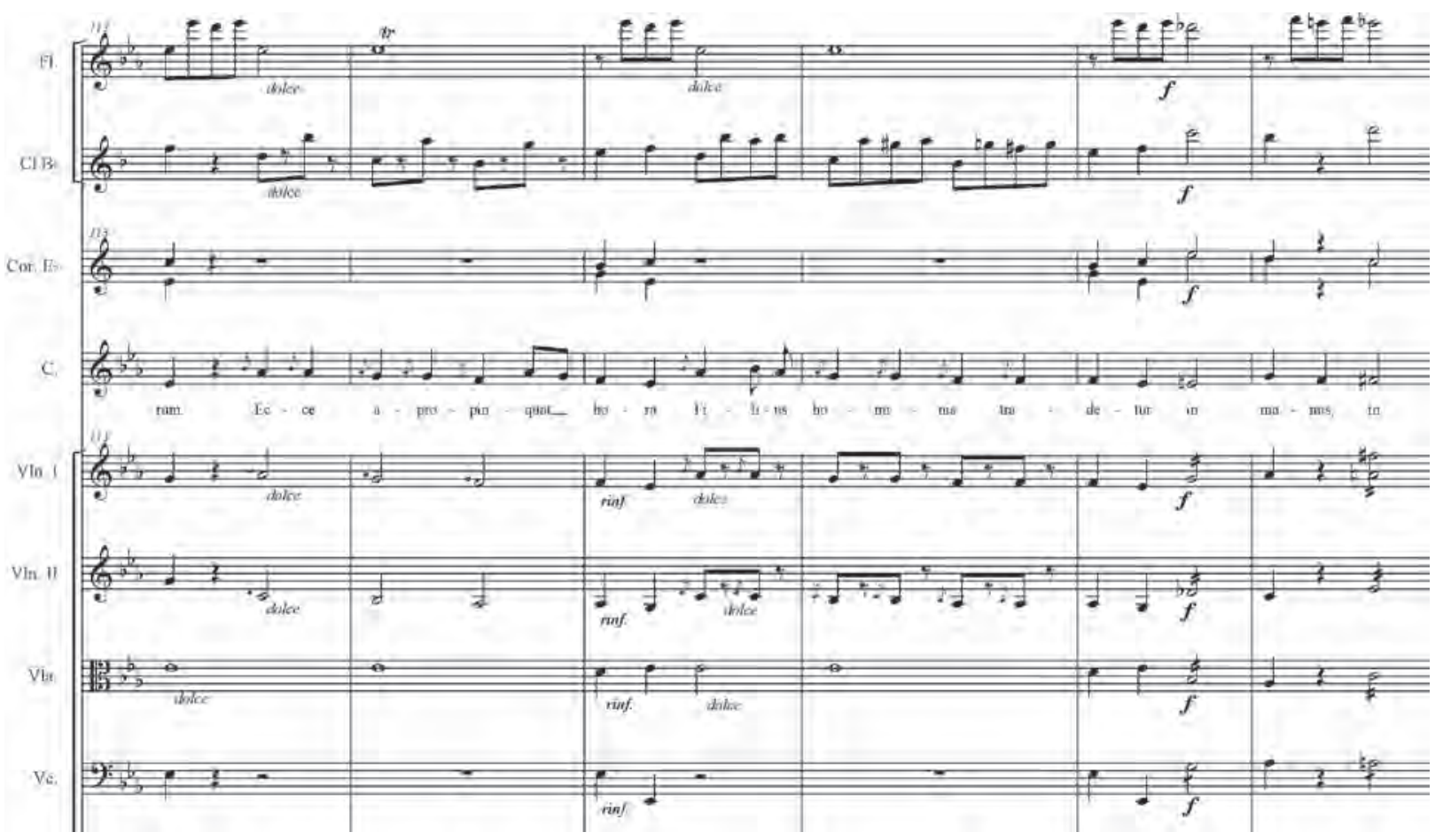

Ex.10: patopeia nas madeiras, verso $2^{\circ}$.

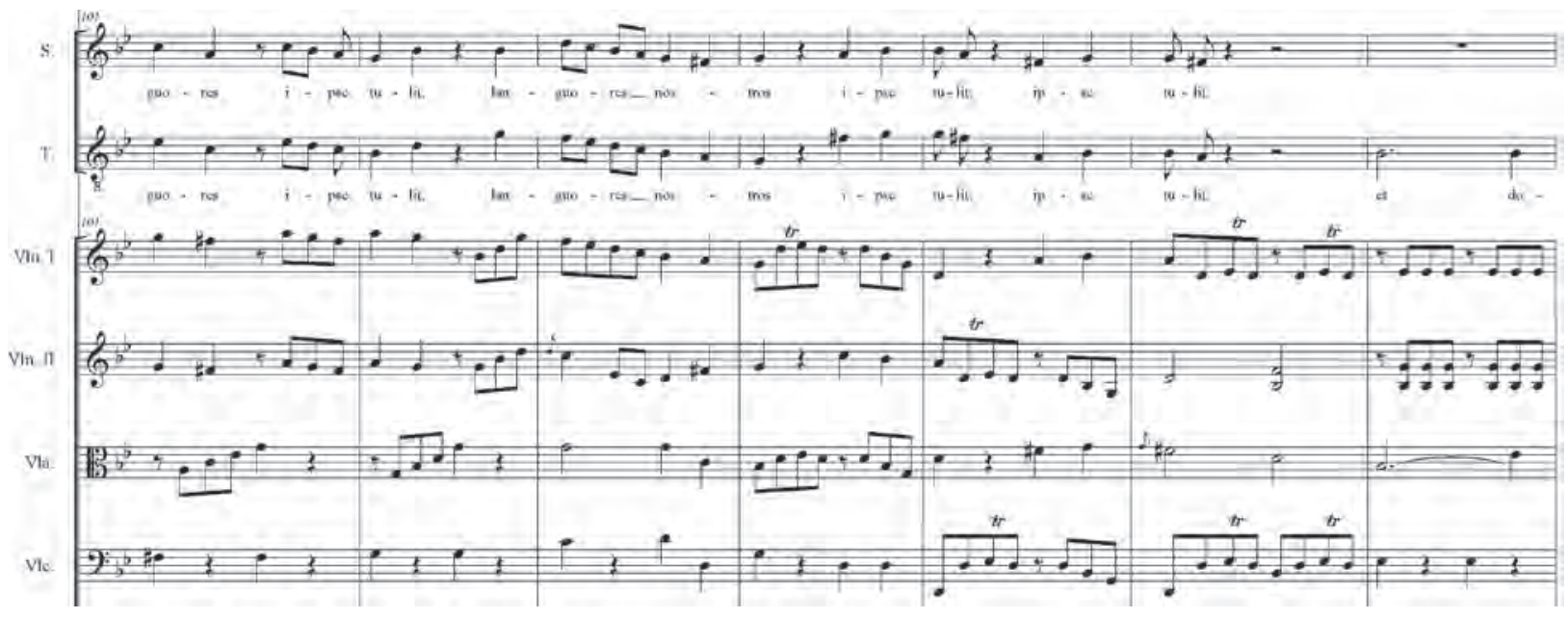

Ex.11: patopeia no verso $3^{\circ}$, realizada pelas cordas.

A $1^{\text {a }}$ prece começa com uma melodia de caráter catabáti$\mathrm{co}$, que é o tema principal de um fugato apresentado por todas vozes do coro cantando "o espírito está pronto", com dobramentos pela orquestra. As entradas deste tema são importantes. Interessante observar que o autor emprega nesta mesma seção de unidade funcional também a figura anábase, podendo se configurar tal emprego um exercício de retórica livre, criado em função do texto.

A figura retórica catábase foi empregada no $2^{\circ}$ verso em passagens melódicas solísticas, tanto na introdução instrumental quanto no solo vocal. Interessante observar que ocorre mais caracteristicamente nos finais de frase, sobre o texto "mão dos pecadores".

\section{Anábase}

A anábase, escala rápida ascendente, é uma figura retórica associada a sentimentos de exaltação ou se relacionando alegoricamente à elevação ou a sentimentos elevados. Trata-se de uma das características principais quando do seu emprego na $1^{\text {a }}$ prece, podendo ser considerada como impulso ou confundida com a figura retórica repetitio ou mesmo clímax. Acontece comentando instrumentalmente o coro, o que a torna uma figura de 


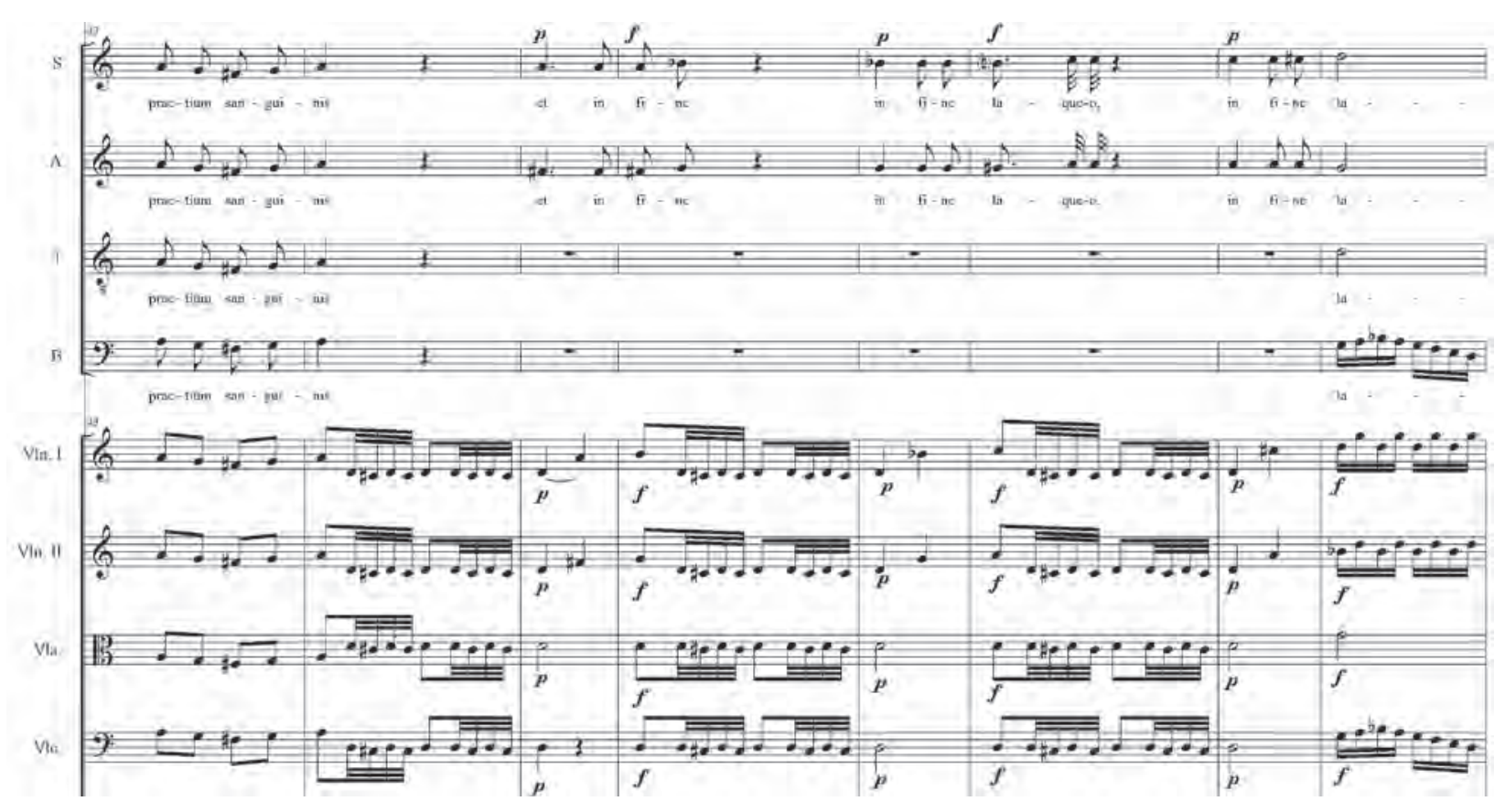

Ex.12: patopeia no verso $3^{\circ}$, realizada pelas cordas.

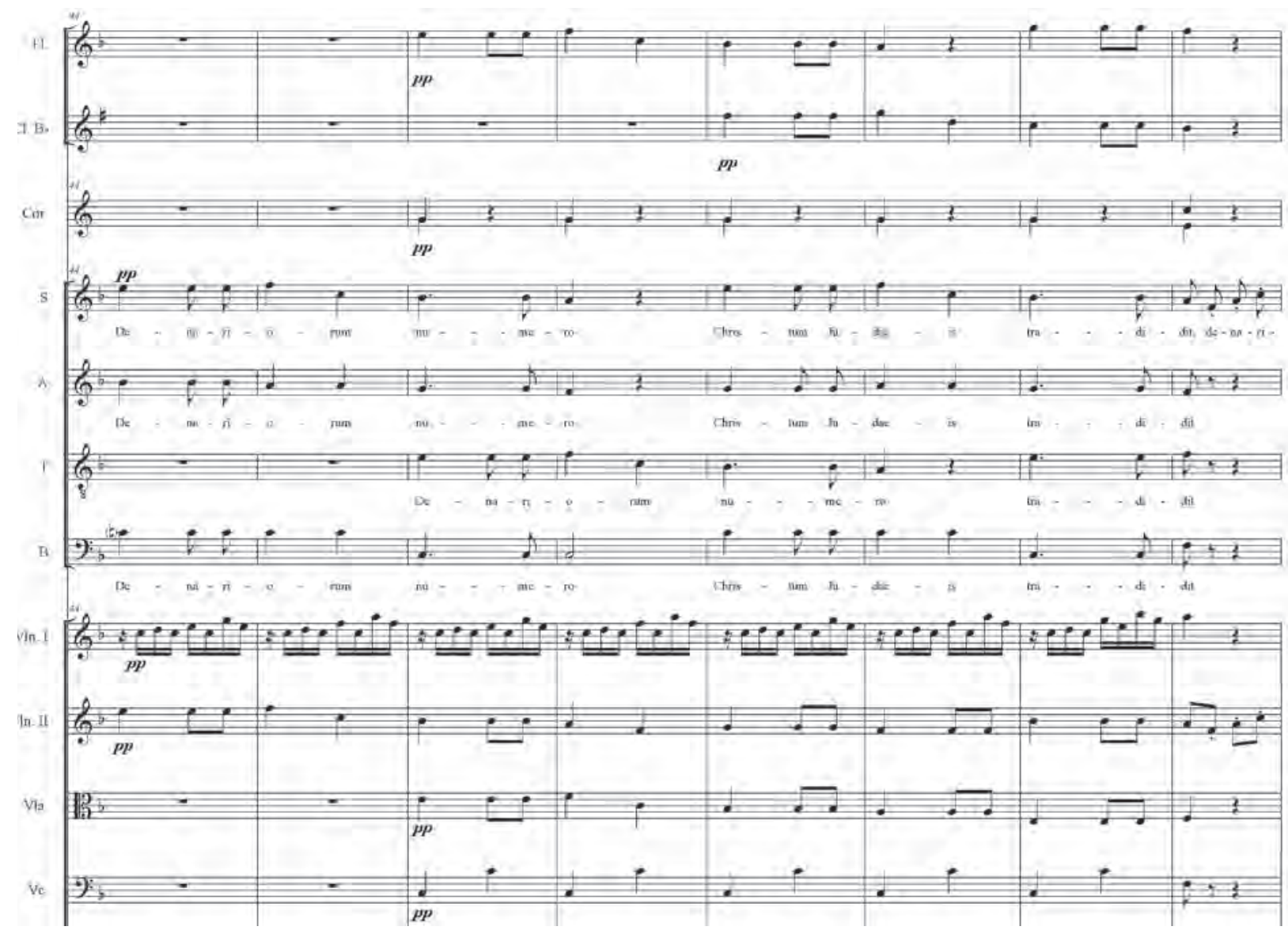

Ex.13: patopeia no verso $3^{\circ}$, realizada pelas cordas 


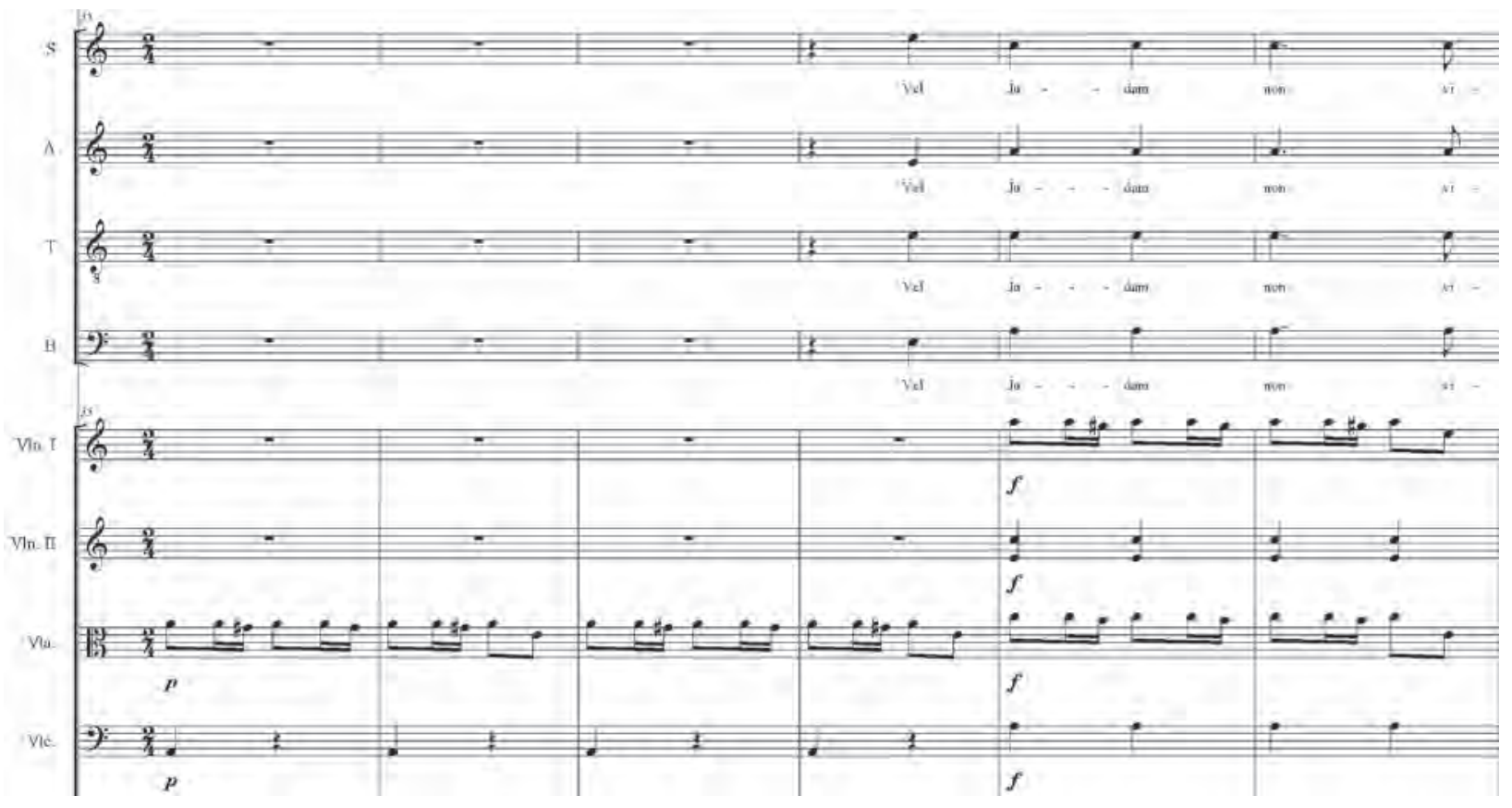

Ex.14: patopeia na prece $8^{a}$, realizada pelas cordas.

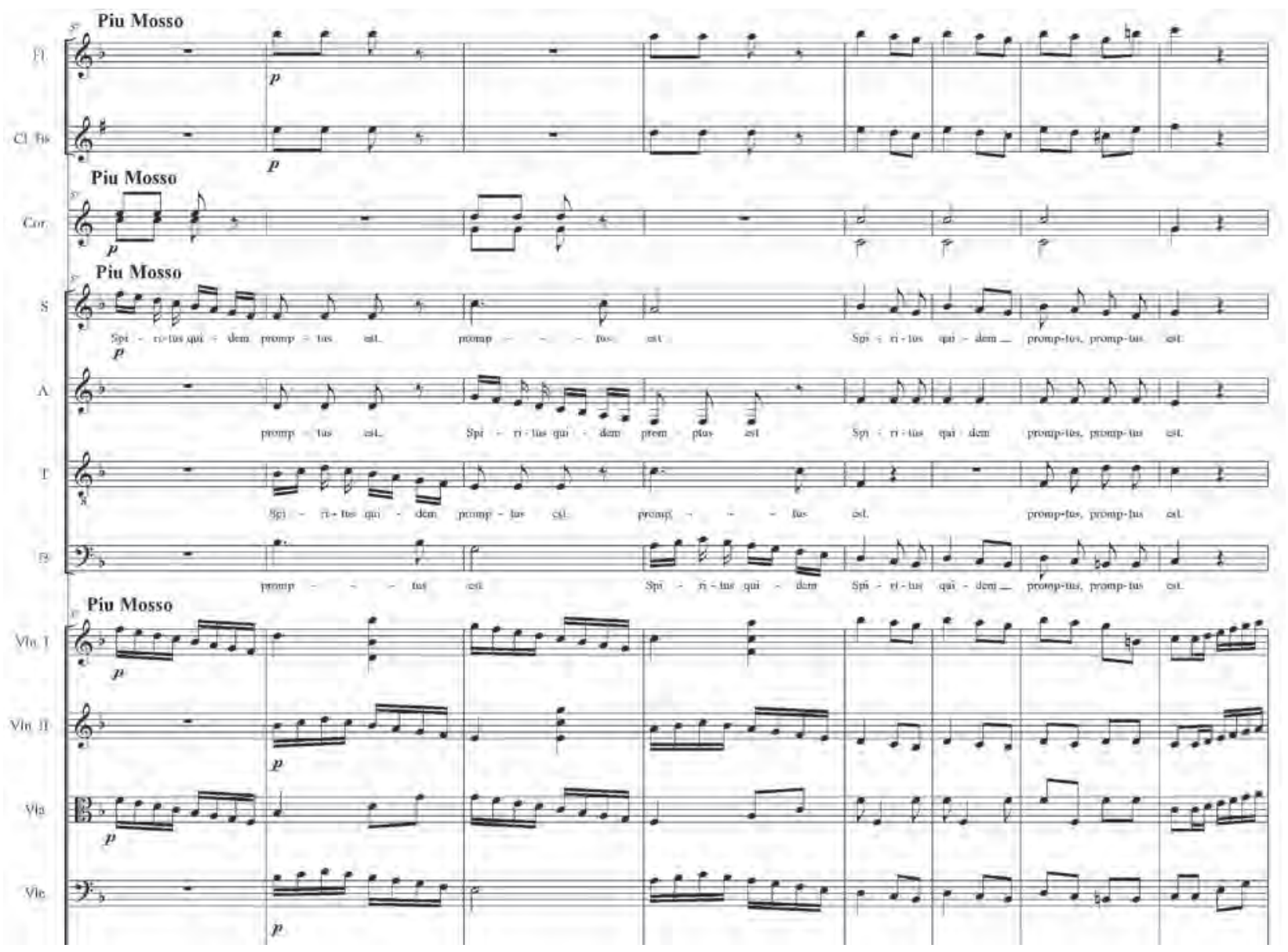

Ex.15: catábase e um compasso de anábase. 
ligação entre seções musicais. É executada também em trechos menores por violinos I e II e violas, ora juntas, ora alternadamente, funcionando como impulso para certas passagens ao longo desta seção de unidade cerimonial.

Escalas anabáticas são empregadas nos c.92 e 93 do $4^{\circ}$ verso, num uníssono das cordas contra a voz solista, que apresenta o texto "melhor seria se [Judas] não tivesse nascido".

$\mathrm{Na} 6^{\mathrm{a}}$ prece a figura retórica anábase serve como resposta ao movimento catabático entre as cordas, em dois compassos de escala que conduzem a um piano súbito.

Outras figuras foram utilizadas por Antônio dos Santos Cunha. Algumas destas apresentam maior complexidade em relação à possibilidade de se identificar a intencionalidade do autor no seu emprego, como a palilogia, cuja estrutura baseada na repetição pode estar escondida nas tendências estilísticas do autor, sendo empregadas por esta razão e não por uma intenção retórica. 0 mesmo se pode dizer da figura clímax, repetições que conduzem a um ponto culminante, que pode se esconder em progressões harmônicas, bem como de muitas outras como as figuras suspiratio, as várias que são chamadas genericamente de hipotiposis (WILSON, 2001), prolongatio e etc.

Uma figura que chama atenção pela sua possivel intencionalidade é a saltus duriusculus, saltos melódicos dissonantes, maiores que a sexta menor que expressam surpresa ou dúvida8. É o que se pode ver na última seção do $6^{\circ}$ responso, c. 25 , em saltos de sétima ascendentes. Pode se observar que é uma figura empregada em um cânone sobre o texto "mas infeliz daquele por quem serei traído".

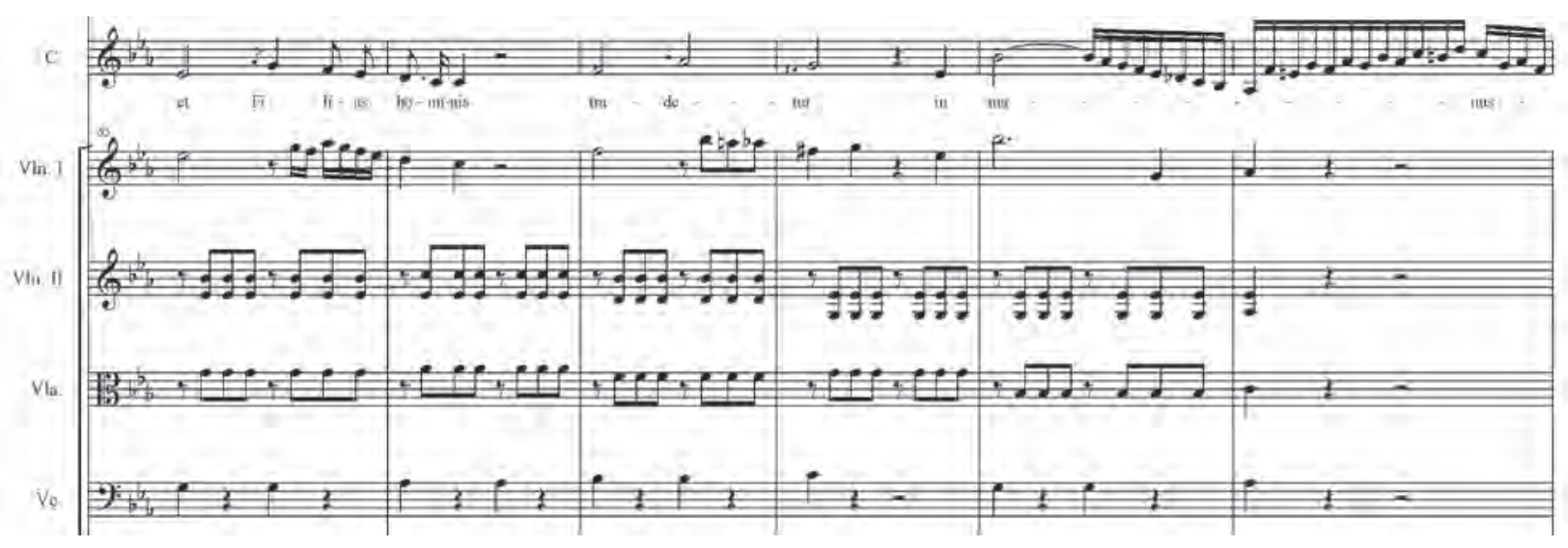

Ex.16: trecho em catábase.

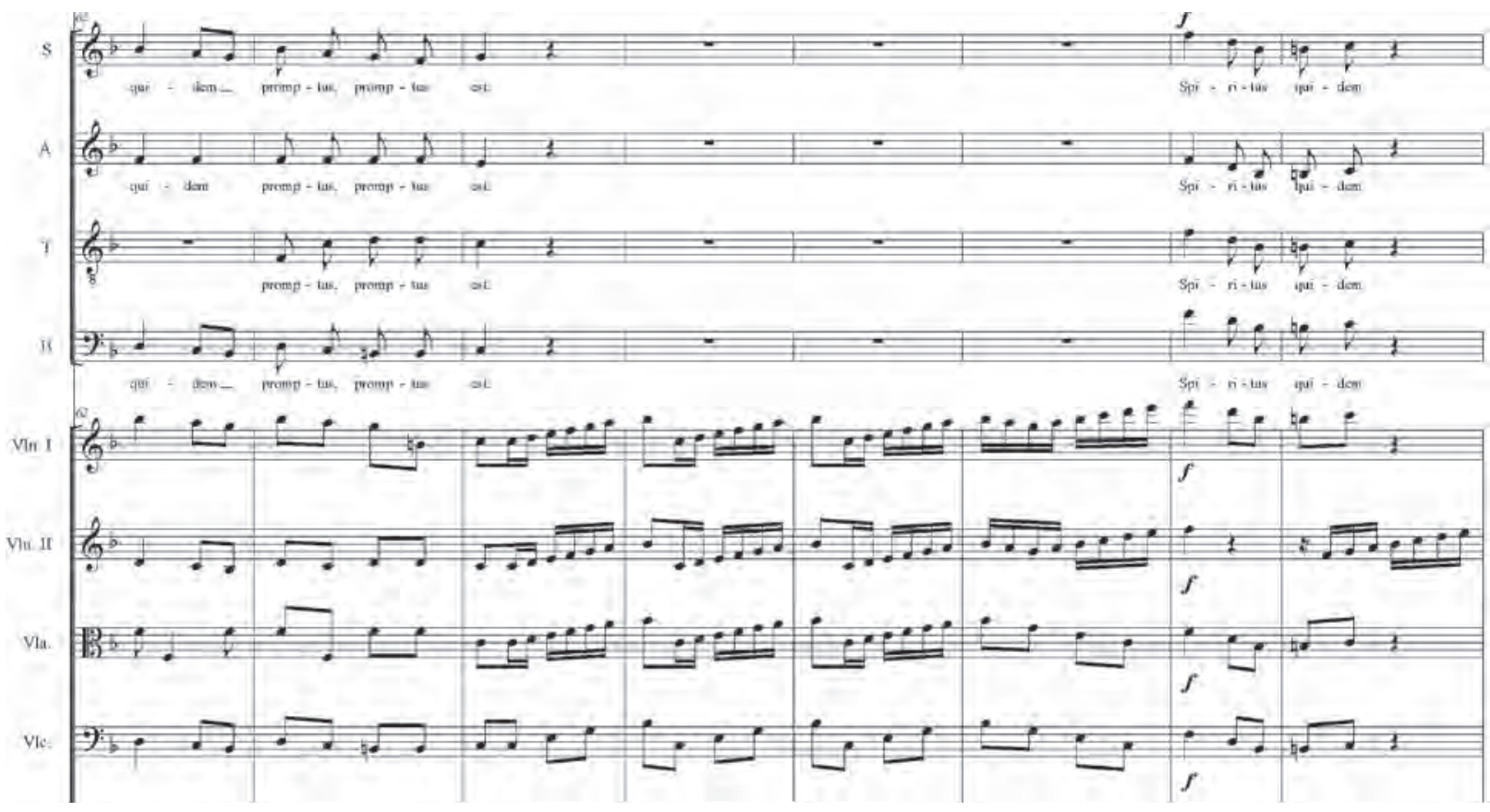

Ex.17: anábase, ligando duas seções. 


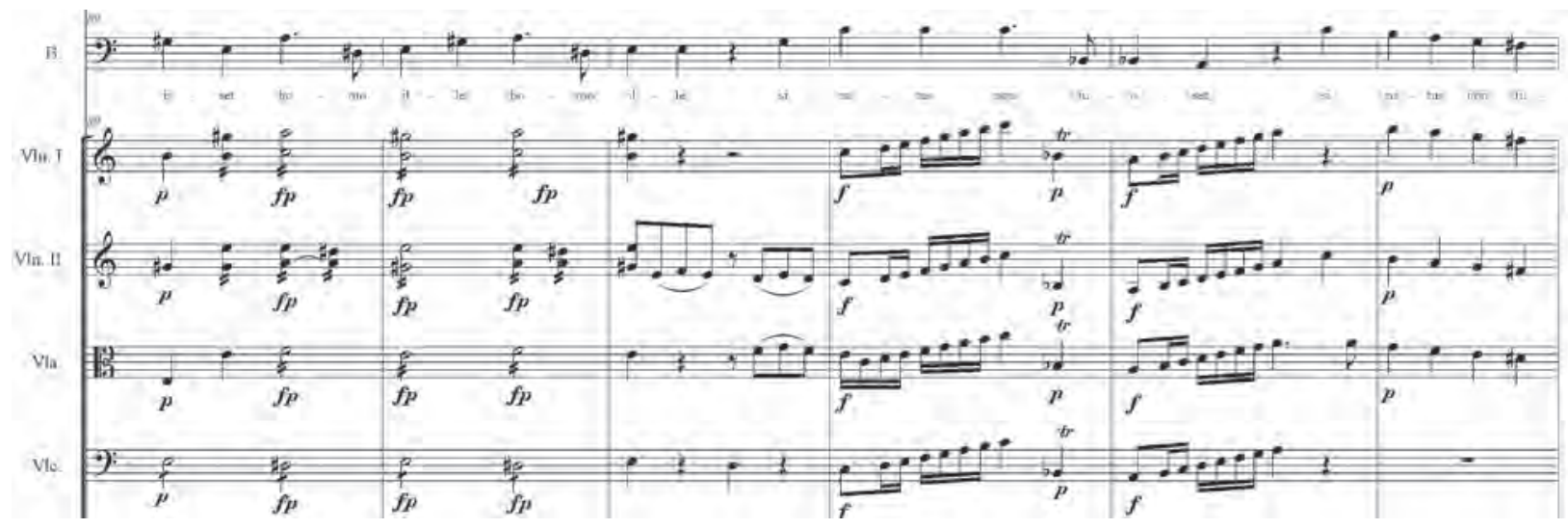

Ex.18: anábase, em uníssono pelas cordas.

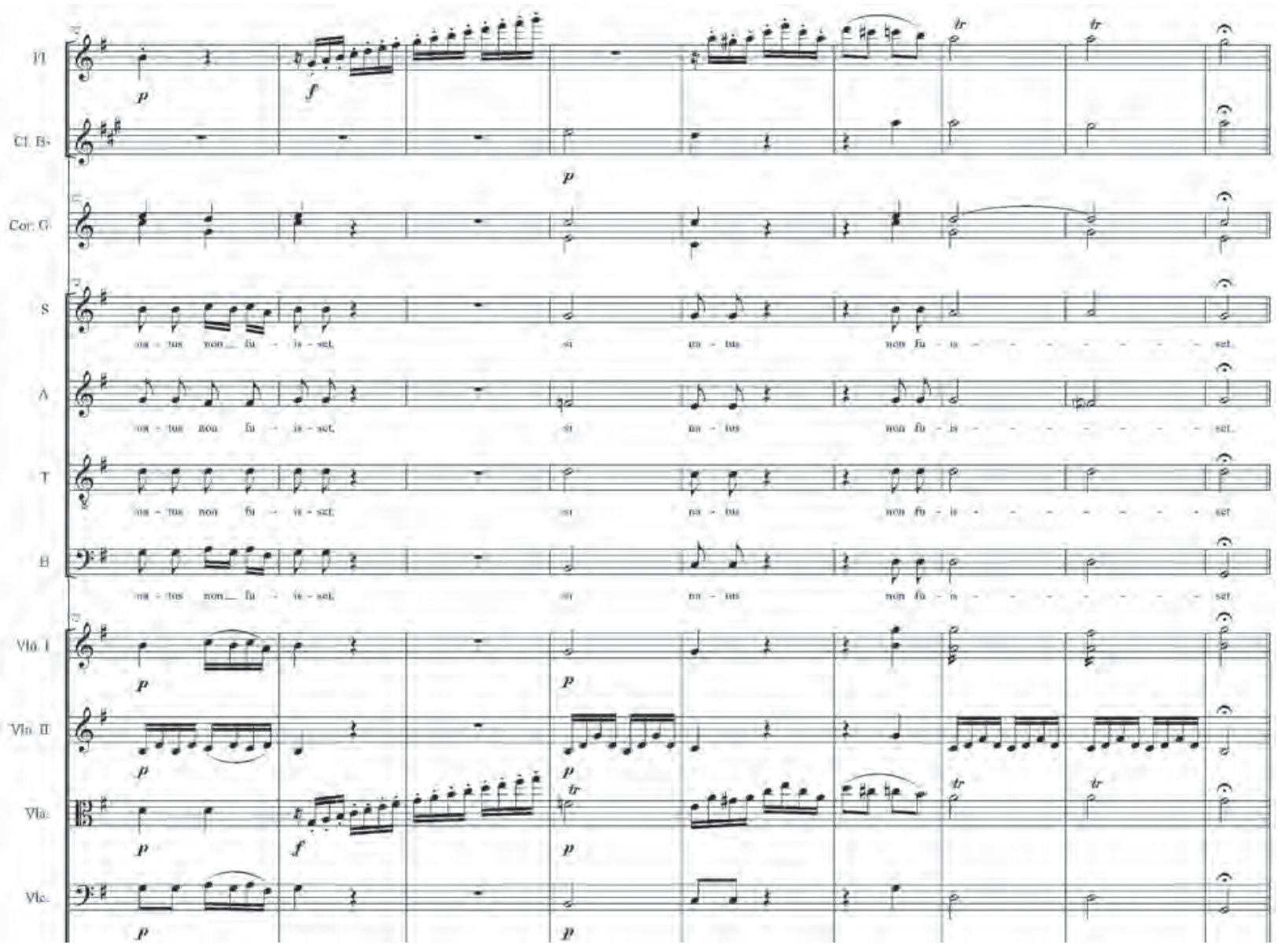

Ex.19: anábase na viola e flauta. 


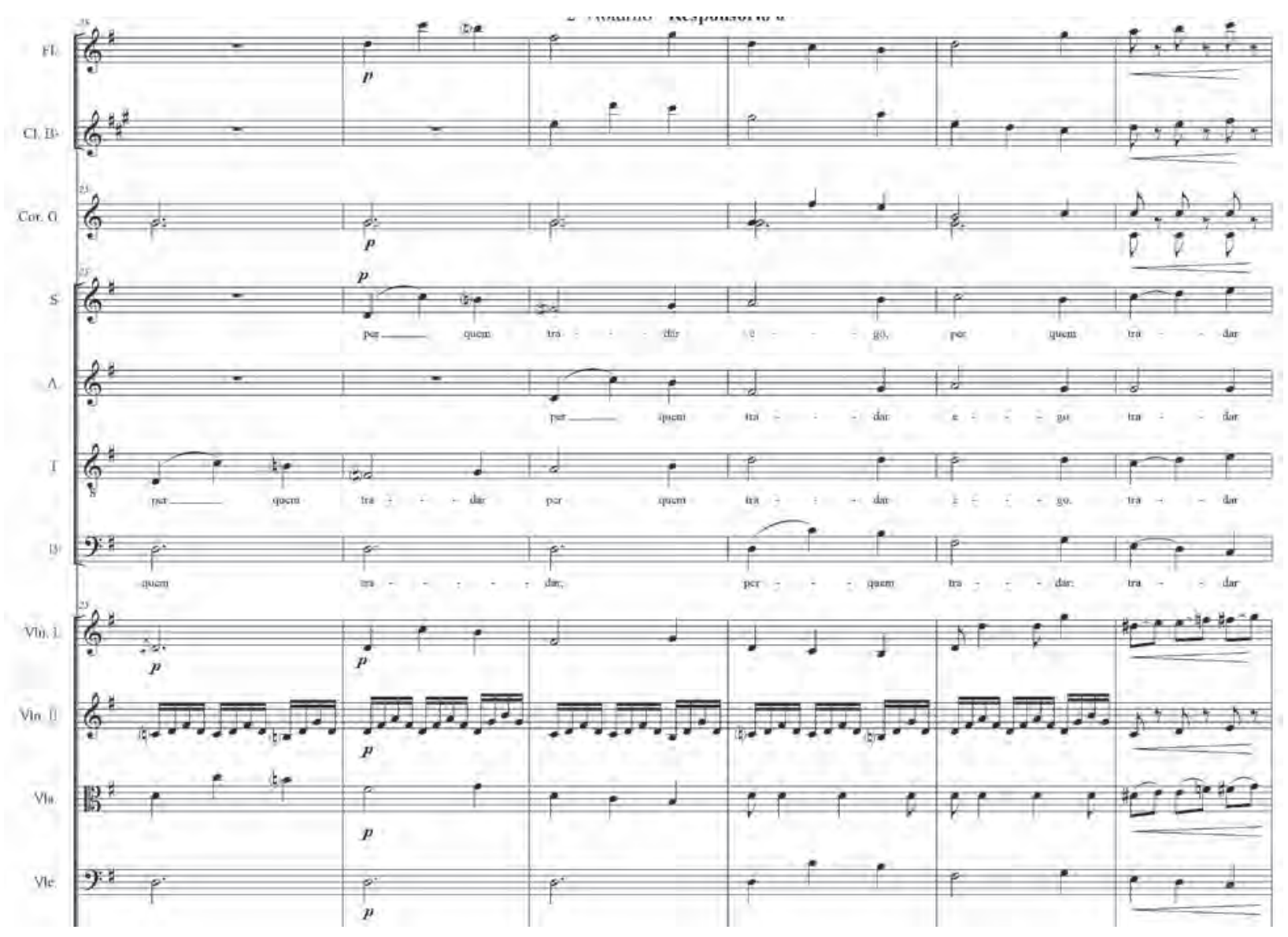

Ex.20: saltus duriusculus no tenor, soprano, contralto, e baixo.

\section{Conclusão}

0 emprego destas figuras de retórica por Antônio dos Santos é indicador da solidez de sua formação e do seu cuidado com os elementos expressivos contidos na liturgia. É interessante observar que a preocupação com a expressão do sentimento, o lado subjetivo da comunicação artística, em detrimento da percepção clara das palavras, expressão mais objetiva se comparada com a música, deixa patente o desejo do autor na provocação ao ouvinte, criando a partir das figuras de retórica, sensações mais profundas e mais afetivas.

0 reconhecimento de estruturas elaboradas como as encontradas nos Responsórios para Quarta Feira Santa, pode se tornar importante ferramenta para a interpretação e compreensão desta obra, fruto da criatividade de um compositor do qual se tem pouquissimas informações, mas cuja obra se alinha com os melhores compositores da história brasileira. 


\section{Referências}

CUNHA, Antônio dos Santos. Responsórios para Quarta, Quinta e Sexta Feira Santa. Partituras autógrafas, manuscritas, constantes do acervo da Orquestra Ribeiro Bastos: São João del-Rei, MG. Encadernado, p.339.

Responsórios para Quarta, e Sexta Feira Santa. Partituras autógrafas, manuscritas, constantes do acervo da Orquestra Ribeiro Bastos: São João del-Rei, MG. Rascunho, p.

217.

Missa Grande. Partituras avulsas, manuscritas, constantes do acervo da Orquestra Ribeiro Bastos: São João del-Rei, MG.

Missa e Credo a 5 Vozes. Partituras manuscritas, disponivel em: <http://acmerj.com.br/CMRJ_CRI_SM82.htm>. Acesso em 12/04/2006.

VIEGAS, Aloísio J. São João del-Rei, 16 abr. 2004, 2 fitas cassete (60 min.). Entrevista concedida a Edilson A. Rocha.

WILSON, Blake e outros. Rethoric. In New Grove Dictionary of Music and Musicians. $2^{\circ}$ ed. Stanley Sadie (ed.). London: Macmillan, 2001.

\section{Notas}

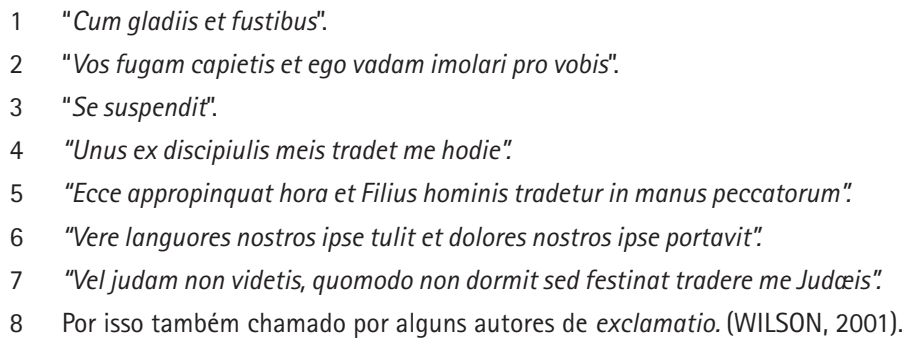

Edilson Rocha é professor adjunto do Departamento de Música da UFSJ, doutor em Regência pela UFBA, com orientação do Prof. Dr. Ricardo Mazzini Bordini, além de mestre por esta mesma instituição, com orientação do Maestro Erick MagaIhães Vasconcelos. É graduado em regência e canto pela Escola de Música da UFMG. Foi professor em oficinas de regência promovidas pela UFS, UNIMONTES e UNESP, e professor de estruturação musical, canto e regência no Conservatório Estadual de Música Padre José Maria Xavier, em São João del-Rei, MG. Regeu diversos grupos corais e orquestrais e têm se dedicado ao estudo, interpretação e divulgação do repertório histórico de Minas Gerais. 